\title{
Oleaginous fungal lipid fermentation on combined acid- and alkali-pretreated corn stover hydrolysate for advanced biofuel production
}

\author{
Zhenhua Ruan, Michael Zanotti, Steven Archer, Wei Liao, Yan Liu* \\ Department of Biosystems and Agricultural Engineering, Michigan State University, East Lansing, MI 48824, USA
}

H I G H L I G H T S

- A novel combined hydrolysis was developed for fungal lipid fermentation.

- Detoxification and pH adjustment were minimized for lignocellulosic biofuel production.

- Lipid accumulation on hydrolysate had a comparable performance with the control.

\section{A R T I C L E I N F O}

\section{Article history:}

Received 19 December 2013

Received in revised form 17 March 2014

Accepted 19 March 2014

Available online 27 March 2014

\section{Keywords:}

Biodiesel

Combined hydrolysis

Lignocellulosic biomass

Oleaginous fungus

Lipid accumulation

\begin{abstract}
A B S T R A C T
A combined hydrolysis process, which first mixed dilute acid- and alkali-pretreated corn stover at a 1:1 $(\mathrm{w} / \mathrm{w})$ ratio, directly followed by enzymatic saccharification without $\mathrm{pH}$ adjustment, has been developed in this study in order to minimize the need of neutralization, detoxification, and washing during the process of lignocellulosic biofuel production. The oleaginous fungus Mortierella isabellina was selected and applied to the combined hydrolysate as well as a synthetic medium to compare fungal lipid accumulation and biodiesel production in both shake flask and $7.5 \mathrm{~L}$ fermentor. Fungal cultivation on combined hydrolysate exhibited comparable cell mass and lipid yield with those from synthetic medium, indicating that the integration of combined hydrolysis with oleaginous fungal lipid fermentation has great potential to improve performance of advanced lignocellulosic biofuel production.
\end{abstract}

(c) 2014 Elsevier Ltd. All rights reserved.

\section{Introduction}

Lignocellulosic biomass is one of the most abundant and renewable sources in nature. Many studies have explored the possibility of using it as a feedstock for advanced biofuels, particularly bioethanol production (Lynd et al., 2005). However, investigations of utilizing lignocellulose for microbial lipid production are still relatively limited. The ability to convert fermentable sugars from lignocellulosic material to lipid in a cost-effective manner is a key technological challenge to fully unlocking the commercial potential for such a process (Lynd et al., 2008). Three major steps identified in the production of microbial oil from lignocellulosic biomass include: hydrolyzing the lignocellulose into fermentable sugars; metabolizing those sugars by oleaginous microorganisms into microbial lipid; and finally generating biodiesel from the microbial lipid (Zhao, 2005). Unfortunately, fermentation of lignocellulosic

\footnotetext{
* Corresponding author. Address: 524 S. Shaw Ln., Room 203, East Lansing, MI 48824, USA. Tel.: +1 517432 7387; fax: +1 5174322892.

E-mail address: liuyan6@msu.edu (Y. Liu).
}

hydrolysate is often preceded by a washing and detoxification steps that require a large amount of water and chemicals (Wooley et al., 1999). In order to develop a technically and economically feasible process for lignocellulosic biofuel production, feedstock pretreatment and enzymatic hydrolysis need to be optimized according to physiological characteristics of the target microorganism.

Lignocellulose is a naturally recalcitrant material consisting of a heterogeneous matrix of three macromolecules: cellulose, hemicellulose and lignin. Physico-chemical pretreatment disrupts the structure of lignocellulosic biomass, removes substrate-specific barriers to enzymatic hydrolysis, and thus improves its digestibility. While pretreatment is a crucial step in the biological conversion of lignocellulose to biofuels, it has likewise been identified as the second most expensive unit in the production of lignocellulosic ethanol preceded by feedstock cost (Mosier et al., 2005). Several thermochemical pretreatment methods have been employed to overcome the recalcitrance nature of lignocellulose, including dilute acid, ammonia fiber expansion, hot water, dilute alkali and organo-solvent methods (Alvira et al., 2010). Among these pretreatment methods, dilute sulfuric acid pretreatment 
has been widely studied due to its efficacy and relatively low cost. It disrupts covalent bonds, hydrogen bonds and Van der Waals forces that link cellulose to lignin and hemicellulose, which consequently enhance cellulose conversion (Li et al., 2010). Sodium hydroxide treatment is another widely used pretreatment method, and has been successfully implemented on a variety of lignocellulosic feedstocks (Xu et al., 2010). The sodium hydroxide pretreatment cleaves the ester bond linking lignin and xylan as well as the glycosidic bond of the polysaccharides, which reduces the degree of polymerization and crystallinity, causes fiber swelling, extracts lignin, and ultimately improves the enzymes access to the polysaccharide chains (Taherzadeh and Karimi, 2008).

The biomass $\mathrm{pH}$ after either sulfuric acid pretreatment (generally lower than 2) or sodium hydroxide pretreatment (usually over 10) needs to be adjusted prior to enzymatic hydrolysis. This requires significant chemical inputs for the $\mathrm{pH}$ adjustment, as well as substantial water for solid washing following the solid-liquid separation, in which the toxin-containing liquid is discarded, and buffer is later added for the enzymatic hydrolysis. In order to cope with this issue, a new combined hydrolysis process was developed in the current study, which mixed the dilute acid and dilute alkali pretreated corn stover slurries at a $1: 1(\mathrm{w} / \mathrm{w})$ ratio ( $\mathrm{pH}$ value of $4.2-5.2)$, removed solid washing and buffer adding, and directly applied enzymes on the neutralized slurry to generate combined hydrolysate.

Combined hydrolysis has its own challenges, such as requiring microorganisms that not only withstand a variety of toxins from pretreatment, but also hold the ability to efficiently ferment both hexose (glucose) and pentose (xylose) in the hydrolysate. There are only a few studies that address both issues. The extreme thermophilic bacterium Thermotoga elfii metabolized glucose and xylose in miscanthus hydrolysate for hydrogen production (de Vrije et al., 2002), and the yeast Scheffersomyces stipites CBS6054 was capable to convert glucose and xylose in giant reed hemicellulose hydrolysate to ethanol (Scordia et al., 2012). Gong et al., reported Cryptococcus curvatus was able to simultaneously consume glucose and xylose from ionic liquid pretreated corn stover (Gong et al., 2013). The yeast strain Trichosporon cutaneum AS 2.571 assimilated glucose and xylose simultaneously during corn stover hydrolysate lipid fermentation (Hu et al., 2011). Our previous studies found that the oleaginous mold Mortierella isabellina ATCC 42613 growing on undetoxified corn stover hydrolysate could accumulate lipid comparable to those from synthetic medium (Ruan et al., 2012, 2013).

Thus, the objectives of the current study are to investigate the performance of combined hydrolysis, and evaluate fungal lipid accumulation on the combined hydrolysate. The integrated process formulates and demonstrates a technically and economically feasible strategy to generate advanced lignocellulosic biofuel.

\section{Methods}

\subsection{Materials}

Corn stover was obtained from Michigan State University Crop and Soil Science Teaching and Research Field Facility. It was airdried and ground using a mill (Willey Mill, Standard Model No. 3, Arthur H. Thomas, Philadelphia, PA) with a $2 \mathrm{~mm}$ size screen; then the ground biomass was sieved to make a particle size distribution less than 30 mesh $(<1.6 \mathrm{~mm})$ but greater than 80 mesh $(>1 \mathrm{~mm})$. The ground corn stover sample was analyzed for cellulose, xylan, and lignin content according to the National Renewable Energy Laboratory's (NREL) analytical procedure for determination of structural carbohydrates and lignin (Sluiter et al., 2008). Results showed a composition of $36.3 \%$ cellulose, $22.0 \%$ xylan, and $18.6 \%$ lignin on a dry weight basis. The moisture content was approximately 7\% (total weight basis). The milled corn stover was kept at $4{ }^{\circ} \mathrm{C}$ for long-term storage.

\subsection{Combined hydrolysis}

Each sample was treated in a screw cap $125 \mathrm{~mL}$ serum bottle and placed in an autoclave (Brinkmann 2540M, Tuttnauer, Hauppauge, NY). Dilute acid and alkali pretreatments were carried out at sulfuric acid and sodium hydroxide concentrations of $2 \%$ $\left(\mathrm{w} \mathrm{w}^{-1}\right)$, respectively. A retention time of $1 \mathrm{~h}$ and reaction temperature of $130^{\circ} \mathrm{C}$ were applied on both pretreatments, which were the optimal conditions for individual pretreatment concluded from previous studies (Ruan et al., 2013; Teater et al., 2011). Biomass concentration for pretreatment was set at $10 \%$ dry matter. After pretreatment, the slurries of dilute acid and alkali treated corn stover were first mixed thoroughly at a $1: 1(\mathrm{w} / \mathrm{w})$ ratio and then directly subjected to enzymatic hydrolysis without $\mathrm{pH}$ adjustment.

The combined slurry was hydrolyzed using commercial enzyme mixtures. The mixtures consisted of cellulase (Accellerase $1500^{\circledR}$, protein content $85.15 \mathrm{mg} \mathrm{mL}^{-1}$, lot number 3016295230; Genencor, Palo Alto, CA) and xylanase (Accellrase XY, protein content $43.63 \mathrm{mg} \mathrm{mL}^{-1}$, lot number 4900667792; Genencor, Palo Alto, CA). Three different enzyme loadings per gram of the initial dry fiber were applied on the combined corn stover slurry: enzyme loading (a) of $21.2 \mathrm{mg}$ Accellerase 1500 and $1.08 \mathrm{mg}$ Accellerase XY, enzyme loading (b) of $10.6 \mathrm{mg}$ Accellerase 1500 and $0.54 \mathrm{mg}$ Accellerase XY, and enzyme loading (c) of $5.4 \mathrm{mg}$ Accellerase 1500 and $0.27 \mathrm{mg}$ Accellerase XY. The enzymatic reaction was carried out for $70 \mathrm{~h}$ at $50{ }^{\circ} \mathrm{C}$ and $150 \mathrm{rpm}$ agitation. The hydrolysate was centrifuged at $7025 \times \mathrm{g}$ for $5 \mathrm{~min}$ to separate the liquid solution from the residual solids. The clear liquid solution was called combined hydrolysate, and stored in a $4{ }^{\circ} \mathrm{C}$ refrigerator for further use.

The sugar yield was used to evaluate the performance of combined hydrolysis. It was determined by the ratio of the measured amount of sugars (glucose and xylose) in combined hydrolysate to the dry weight of initial biomass and also calculated as the percentage of theoretical glucose and xylose yield from initial cellulose and xylan in corn stover.

\subsection{Microorganism and culture conditions}

Seed and fermentation media for $M$. isabellina culture were previously reported (Ruan et al., 2012, 2013). Yeast extract (DOT Scientific Inc., Burton, MI) was used as the sole nitrogen source. The carbon sources were the combined corn stover hydrolysate and the control of synthetic medium (composed of a mixture of glucose, xylose and acetate, with concentrations similar to those found in the combined hydrolysate). The nitrogen source in the culture media was $3.6 \mathrm{~g} \mathrm{~L}^{-1}$ yeast extract. The mineral salts in the culture media were $1 \mathrm{~g} \mathrm{~L}^{-1} \mathrm{KH}_{2} \mathrm{PO}_{4}, 0.5 \mathrm{~g} \mathrm{~L}^{-1} \mathrm{MgCl}_{2} \cdot 6 \mathrm{H}_{2} \mathrm{O}$, $0.0014 \mathrm{~g} \mathrm{~L}^{-1} \mathrm{ZnSO}_{4} \cdot 7 \mathrm{H}_{2} \mathrm{O}, 0.0016 \mathrm{~g} \mathrm{~L}^{-1} \mathrm{MnSO}_{4} \cdot \mathrm{H}_{2} \mathrm{O}, 0.0036 \mathrm{~g} \mathrm{~L}^{-1}$ $\mathrm{CoCl}_{2} \cdot 6 \mathrm{H}_{2} \mathrm{O}$, and $0.00275 \mathrm{~g} \mathrm{~L}^{-1} \mathrm{FeSO}_{4} \cdot 7 \mathrm{H}_{2} \mathrm{O}$. The $\mathrm{pH}$ of the fermentation media was adjusted to $6.0 \pm 0.1$ before autoclaving. $250 \mathrm{~mL}$ Erlenmeyer flasks filled with $50 \mathrm{~mL}$ of media were sterilized at $121{ }^{\circ} \mathrm{C}$ for $15 \mathrm{~min}$. The medium was inoculated with a $10 \%$ $\left(\mathrm{v} \mathrm{v}^{-1}\right)$ seed and cultivated at $25 \pm 1^{\circ} \mathrm{C}$ on a rotary shaker (Thermal Scientific, Odessa, Texas) with an agitation speed of $180 \mathrm{rpm}$. The fungal lipid culture using combined hydrolysate medium was also scaled up and carried out at a $7.5 \mathrm{~L}$ fermentor (New Brunswick Bioflo $115^{\circledR}$ bioreactor, Eppendorf, Inc., CT). Compressed air was used and the dissolved oxygen was maintained between 1.2 and $2.4 \mathrm{mg} / \mathrm{L}$ with $1 \mathrm{vvm}$ (volume air per volume medium per minute) aeration rate and $200 \mathrm{rpm}$ agitation. Fermentation $\mathrm{pH}$ was kept at around 6.0 and temperature was controlled at $25^{\circ} \mathrm{C}$ during the culture. Substrate concentrations (glucose, xylose and acetate) were 
monitored to determine the completion of fermentation for both flask and fermentor cultures.

\subsection{Biodiesel production}

The lipids in fungal cell mass were extracted using a mixed solvent of hexane and isopropanol at a hexane:isopropanol ratio of $3: 2\left(\mathrm{v} \mathrm{v}^{-1}\right)$ (Halim et al., 2012). The extracted lipids were directly converted into fatty acid methyl esters (FAMEs) using a transesterification approach (Indarti et al., 2005). The resulted FAMEs were analyzed by GC-MS and biodiesel yield was calculated based on the FAMEs.

\subsection{Analytical methods}

Glucose, xylose, acetic acid, furfural and hydroxymethylfurfural (HMF) in the combined hydrolysate as well as fermentation broth were determined by High Performance Liquid Chromatography (HPLC) (Shimadzu prominence), which equipped with a Bio-rad Aminex HPX-87H analytical column and a refractive index detector. The mobile phase was $0.005 \mathrm{~mol} \mathrm{~L}^{-1}$ sulfuric acid at a flow rate of $0.6 \mathrm{~mL} \mathrm{~min}^{-1}$. The oven temperature was set at $65^{\circ} \mathrm{C}$. HPLC grade standards including glucose (Catalog Number: 49158), xylose (Catalog Number: 95729), sodium acetate (Catalog Number: S8750), HMF (Catalog Number: 53407), furfural (Catalog Number: 185914) were purchased from Sigma-Aldrich, St. Louis, MO.

Mycelia were collected by filtration and washed twice with distilled water. Cell mass was determined by drying at $75 \pm 1{ }^{\circ} \mathrm{C}$ to obtain a consistent weight. Dried mycelia were ground in a mortar and used for lipid extraction. Total lipid was determined gravimetrically (Ruan et al., 2012).

FAME analysis was performed using an Agilent $6890 \mathrm{~N}$ gas chromatograph equipped with an Agilent DB-23 column $(30 \mathrm{~m}$, $250 \mu \mathrm{m}, 0.25 \mu \mathrm{m}$ ) and a CTC PAL auto-sampler. The GC was connected to an Agilent 5975 single quadrupole mass spectrometer equipped with a $70 \mathrm{eV}$ electron ionization source. Helium was used as the carrier gas at a flow rate of $1.3 \mathrm{~mL} / \mathrm{min}$. The inlet was operated in the splitless mode at a temperature of $250^{\circ} \mathrm{C}$. An injection volume of $1 \mu \mathrm{L}$ was used. The column temperature was programmed as follows: holding at $50{ }^{\circ} \mathrm{C}$ for $2 \mathrm{~min}$, increasing to $180^{\circ} \mathrm{C}$ at $10^{\circ} \mathrm{C} / \mathrm{min}$ and holding at $180^{\circ} \mathrm{C}$ for $5 \mathrm{~min}$, and further increasing to $240^{\circ} \mathrm{C}$ at $5^{\circ} \mathrm{C} / \mathrm{min}$ and holding at $240^{\circ} \mathrm{C}$ for $1 \mathrm{~min}$. A mixture of C8-C24 FAMEs (Catalog No: 18918-1 AMP, SigmaAldrich, St. Louis, MO) was used as the external standards. The mixture included methyl arachidate, methyl behenate, methyl decanoate, methyl cis-13-docosenoate, methyl dodecanoate, methyl linoleate, methyl linolenate, methyl myristate, methyl octanoate, methyl oleate, methyl palmitate, methyl palmitoleate and methyl stearate, methyl tetracosanoate, Nonadecanoic acid methyl ester (C19:0) (Catalog No: 646-30-0, Sigma-Aldrich, St. Louis, MO) was used as the internal standard $(10 \mu \mathrm{g} / \mathrm{mL})$.

\subsection{Statistical analysis}

A general linear model using $R$ software ( $R$ Version 2.15.0, Vienna, Austria) was applied to perform an analysis of variance (ANOVA) and multiple comparisons on the experimental data.

\section{Results and discussion}

\subsection{Combined hydrolysis of corn stover for fermentable sugars production}

The combined hydrolysis of corn stover was performed by applying enzymatic hydrolysis on mixed dilute acid and alkali- pretreated corn stover slurry. Three different enzyme loadings as indicated in Section 2.2 were applied. Fig. 1 showed the time course of glucose and xylose concentrations as a function of various enzyme loadings for combined hydrolysis. Glucose concentration indicated the typical batch hydrolysis pattern, with a rapid glucose release at the beginning of the process, followed by a plateau with litter further increase. Enzyme loading (a) on the combined slurry released $28 \mathrm{~g} \mathrm{~L}^{-1}$ glucose at $17 \mathrm{~h}$, which was $92 \%$ of that released at $70 \mathrm{~h}$ of enzymatic hydrolysis; while in the same reaction duration, 24 and $14 \mathrm{~g} \mathrm{~L}^{-1}$ glucose were produced with enzyme loadings (b) and (c), respectively, which corresponded to $80 \%$ and $62 \%$ of those generated at $70 \mathrm{~h}$. The pattern of xylan hydrolysis was different from cellulose hydrolysis. Xylose concentrations were gradually increased with the progression of reaction time (Fig. 1). Enzyme loading (a) released $84 \%\left(16 \mathrm{~g} \mathrm{~L}^{-1}\right)$ of the final xylose generated at $70 \mathrm{~h}$ enzymatic hydrolysis; and enzyme loadings (b) and (c) delivered $80 \%$ and $77 \%$ of that produced at $70 \mathrm{~h}$ with corresponding concentration of 13 and $10.5 \mathrm{~g} \mathrm{~L}^{-1}$.

Table 1 and Fig. 2 presented the combined sugar (glucose + xylose) yields and inhibitor concentrations from combined hydrolysis. The sugar yield at enzyme loading (a) reached $0.45 \mathrm{~g} \mathrm{~g}^{-1}$ dry initial biomass, which was $74 \%$ of the theoretical yield. While enzyme loadings (b) and (c) had the sugar yields of $0.41 \mathrm{~g} \mathrm{~g}^{-1}$ (67\% of the theoretical yield) and $0.32 \mathrm{~g} \mathrm{~g}^{-1}$ (54\% of the theoretical yield) dry initial biomass, respectively. Statistical analysis elucidated that there was no significant $(p>0.05)$ difference on combined sugar yield between enzyme loadings (a) and (b), while the combined sugar yield from enzyme loading (c) was significantly $(p<0.05)$ lower than the other two enzyme loadings. Therefore, considering both enzyme loading and hydrolysis performance, enzyme loading (b) (50\% of the enzyme loading (a)) was chosen to prepare the combined hydrolysate for the following fermentation experiments.

\subsection{Microbial lipid fermentation from combined hydrolysate}

\subsubsection{Fungal lipid production of shake flask culture}

Microbial lipid fermentations using M. isabellina ATCC 42613 on the combined hydrolysate and synthetic medium were carried out to elucidate the effect of combined hydrolysis on fungal lipid accumulation. The carbon sources in the combined hydrolysate media for the shake flask culture were $22.2 \mathrm{~g} \mathrm{~L}^{-1}$ glucose, $12 \mathrm{~g} \mathrm{~L}^{-1}$ xylose, and $3.7 \mathrm{~g} \mathrm{~L}^{-1}$ acetate. While the synthetic medium included $17.9 \mathrm{~g} \mathrm{~L}^{-1}$ glucose, $12.5 \mathrm{~g} \mathrm{~L}^{-1}$ xylose, and $3.9 \mathrm{~g} \mathrm{~L}^{-1}$ acetate. Changes of cell mass, lipid yield, lipid content, glucose, xylose and acetate during the fermentation were presented in Fig. 3.

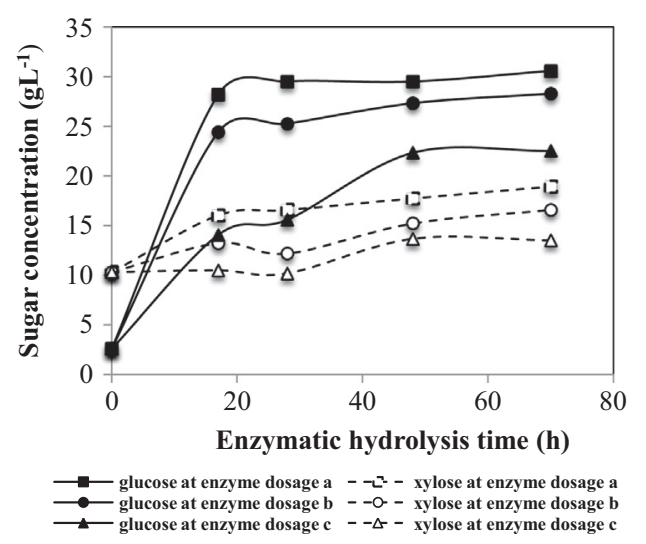

Fig. 1. Change in monomeric glucose (Glc) and xylose (Xyl) concentrations during enzymatic hydrolysis of combined slurry. (1) The data represent the average of two replicates. 
Table 1

Fermentable sugars yield and inhibitory compound concentrations at the end of combined hydrolysis (70 h).

\begin{tabular}{|c|c|c|c|c|c|}
\hline \multirow[t]{2}{*}{ Enzyme loadings } & \multicolumn{2}{|l|}{ Sugars } & \multicolumn{3}{|c|}{ Inhibitory compounds } \\
\hline & Glu+Xyl ( g g $^{-1}$ dry biomass) & Glu+Xyl (\% of theoretical yield) & $\begin{array}{l}\text { Acetate } \\
\left(\mathrm{g} \mathrm{L}^{-1}\right)\end{array}$ & $\begin{array}{l}\text { HMF } \\
\left(\mathrm{mg} \mathrm{L}^{-1}\right)\end{array}$ & $\begin{array}{l}\text { Furfural } \\
\left(\mathrm{g} \mathrm{L}^{-1}\right)\end{array}$ \\
\hline $21.2 \mathrm{mg}$ Accellerase $1500+1.08 \mathrm{mg}$ Accellerase $\mathrm{XY}$ & 0.446 & 74.2 & 4.48 & 11.9 & 0.147 \\
\hline $10.6 \mathrm{mg}$ Accellerase $1500+0.54 \mathrm{mg}$ Accellerase XY & 0.404 & 67.2 & 4.62 & 11.8 & 0.142 \\
\hline $5.4 \mathrm{mg}$ Accellerase $1500+0.27 \mathrm{mg}$ Accellerase $\mathrm{XY}$ & 0.324 & 54.0 & 4.38 & 12.5 & 0.160 \\
\hline
\end{tabular}

(1) NREL's analysis of structural carbohydrate and lignin: cellulose: 36.3\% (w/w); xylan: 22.0\% (w/w); lignin: 18.6\% (w/w).

(2) Dilute acid and alkali pretreatment was carried out at $10 \%(\mathrm{w} / \mathrm{w})$ dry solids.

(3) Data represent the average of two replicates.

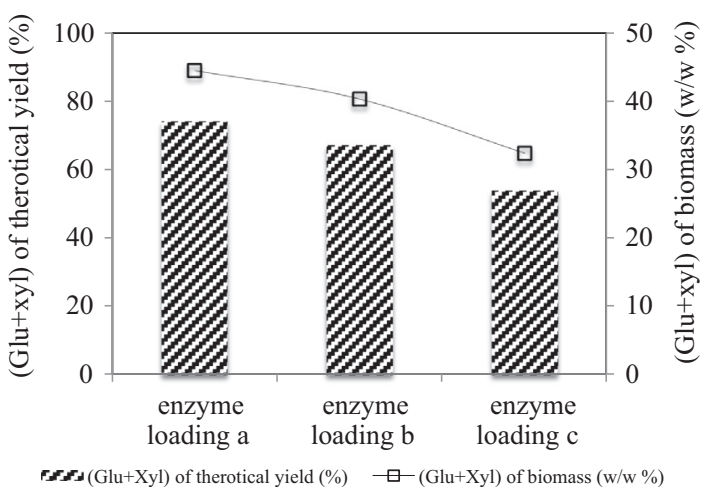

Fig. 2. Effect of enzyme loadings on combined glucose and xylose yield. (1) Sugar yield was calculated as the percent of theoretical combined glucose and xylose yield from corn stover. (2) Sugar yield was determined by the ratio of the measured amount of sugars (glucose and xylose) in combined hydrolysates to the dry weight of initial corn stover. The enzyme loading per gram dry mass for each treatment was at three levels, loading (a: $21.2 \mathrm{mg}$ Accellerase 1500 and $1.08 \mathrm{mg}$ Accellerase XY), loading (b: $10.6 \mathrm{mg}$ Accellerase 1500 and $0.54 \mathrm{mg}$ Accellerase XY), loading (c: $5.4 \mathrm{mg}$ Accellerase 1500 and $0.27 \mathrm{mg}$ Accellerase XY). (3) Data represent the average of two replicates.

The trends of sugar and acetate consumption, cell mass and lipid accumulation were similar for fermentation on both combined hydrolysate and synthetic medium. However, fungal growth on the combined hydrolysate was delayed by approximately $20 \mathrm{~h}$ compared to the fermentation on synthetic medium. The concentrations of cell mass and lipid from the fermentation on synthetic medium were quickly increased to 5.26 and $0.67 \mathrm{~g} \mathrm{~L}^{-1}$, respectively in the first $15 \mathrm{~h}$ of the culture, and lipid content in the cell mass was about $13 \%(\mathrm{w} / \mathrm{w})$. While, only slight increase in cell mass and small consumption of glucose were observed for the culture on the combined hydrolysate, which the cell mass and lipid concentration were 1.7 and $0.22 \mathrm{~g} \mathrm{~L}^{-1}$ at $15 \mathrm{~h}$. With the extension of the culture, the fermentation on synthetic medium continuously accumulated cell mass and lipid. The cell mass, lipid concentration and lipid content increased to $12.28 \mathrm{~g} \mathrm{~L}^{-1}, 3.89 \mathrm{~g} \mathrm{~L}^{-1}$, and $35.16 \%\left(\mathrm{w} \mathrm{w}^{-1}\right)$ at $40 \mathrm{~h}$. The fermentation was then slowed down after glucose, xylose and acetate were completely utilized. The maximum cell mass and lipid concentration of 14.9 and $5.4 \mathrm{~g} \mathrm{~L}^{-1}$ were achieved at $70 \mathrm{~h}$ with a lipid content of $36.6 \%\left(w^{-1}\right)$. Meanwhile, the fermentation on combined hydrolysate started taking off after $15 \mathrm{~h}$ of the culture. It took $86 \mathrm{~h}$ to consume all of the glucose, xylose, and acetate. The maximum cell mass and lipid concentrations of 16.8 and $5.1 \mathrm{~g} \mathrm{~L}^{-1}$ were reached at $93 \mathrm{~h}$ with a lipid content of $30 \%\left(\mathrm{w} \mathrm{w}^{-1}\right)$. Considering lipid yield with respect to sugars and acetate in the medium, the fermentation on the combined hydrolysate had $0.14 \mathrm{~g} \mathrm{~g}^{-1}$, which is slightly lower than $0.16 \mathrm{~g} \mathrm{~g}^{-1}$ of the fermentation from the synthetic medium (Table 3 ). The prolonged lag phase and lower lipid yield may be caused by various inhibitory compounds in the combined hydrolysate such as furfural, HMF, acetate (Table 1)
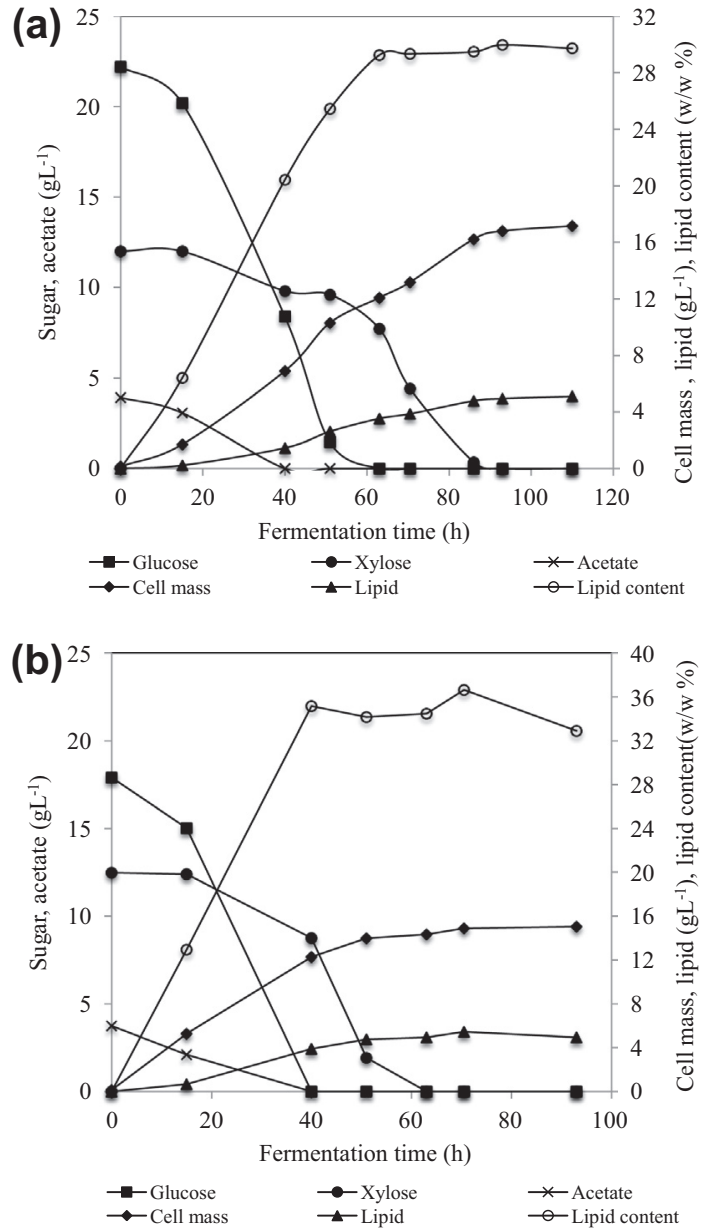

Fig. 3. M. isabellina fermentation of lipid accumulation on combined-hydrolysate (a) and synthetic medium (b). (1) Data represent the average of two replicates

(Ruan et al., 2012, 2013). Similar inhibitory effects of such compounds were observed by other researchers (Chen et al., 2009; Hu et al., 2009; Huang et al., 2009).

Despite a slightly lower yield and longer lag phase, $M$. isabellina lipid accumulation on the combined corn stover hydrolysate demonstrated superior lipid productivity compared to those on other lignocellulosic hydrolysates (Table 2). In addition, using both acid and base to effectively pretreat the feedstock, instead of just using either of them to neutralize the pretreated slurry, also significantly enhances the efficiency of chemical use during the refining process (50\% reduction of chemical loading per unit feedstock), and alleviates the pressure on the desalination of the fermentation effluent treatment. Thus, combined hydrolysis has potential to be integrated with oleaginous fungal lipid accumulation for advanced lipid-based fuel production. 
Table 2

Lipid production of M. isabellina from various feedstocks.

\begin{tabular}{|c|c|c|c|c|c|}
\hline Strain & Feedstocks & Lipid yield $\left(\mathrm{g} \mathrm{L}^{-1}\right)$ & Lipid content (\%) & Lipid productivity $\left(\mathrm{g} \mathrm{L}^{-1} \mathrm{~h}^{-1}\right)$ & References \\
\hline M. isabellina ATHUM2935 & Starch & 3.7 & 35.6 & 0.021 & Papanikolaou et al. (2007) \\
\hline M. isabellina ATHUM2935 & Raw glycerol & 4.4 & 51.0 & 0.0105 & Papanikolaou et al. (2008) \\
\hline M. isabellina ATHUM2935 & Cheese whey & 4.0 & 17.3 & 0.0234 & Vamvakaki et al. (2010) \\
\hline M. isabellina ATHUM2935 & Raw glycerol & 3.3 & 53.2 & 0.0092 & Fakas et al. (2009) \\
\hline M. isabellina ATHUM2935 & Rice hull & 3.6 & 64.3 & 0.0096 & Economou et al. (2011b) \\
\hline M. isabellina ATHUM2935 & Sweet sorghum & 9.2 & 43 & 0.038 & Economou et al. (2011a) \\
\hline M. isabellina NRRL 1757 & Wheat straw & 4.36 & 36.3 & 0.03 & Zeng et al. (2013) \\
\hline M. isabellina ATHUM2935 & Sweet sorghum & $110(\mathrm{mg} / \mathrm{gds})^{\mathrm{f}}$ & 25 & 0.055 & Economou et al. (2010) \\
\hline M. isabellina IFO 7884 & Soybean hull & 47.9 (mg/gds) & N.A. & N.A. & Zhang and Hu (2012) \\
\hline \multirow[t]{7}{*}{ M. isabellina ATCC42613 } & Corn stover ${ }^{a}$ & 25.2 (mg/gds) & 34.4 & 0.05 & Ruan et al. (2012) \\
\hline & Corn stover $^{\mathrm{b}}$ & 16.1 (mg/gds) & 29.5 & 0.027 & Ruan et al. (2012) \\
\hline & Corn stover ${ }^{c}$ & 62.8 (mg/gds) & 24.8 & 0.036 & Ruan et al. (2013) \\
\hline & Switchgrass & 72.2 (mg/gds) & 35.6 & 0.0375 & Ruan et al. (2013) \\
\hline & Miscanthus & 49.9 (mg/gds) & 32.2 & 0.032 & Ruan et al. (2013) \\
\hline & Giant reed & 42.1 (mg/gds) & 21.2 & 0.022 & Ruan et al. (2013) \\
\hline & Corn stover ${ }^{\mathrm{d}}$ & 60 (mg/gds) & 30.0 & 0.055 & Current study \\
\hline
\end{tabular}

N.A., not available.

a $1 \%\left(w^{-1}\right)$ sulfuric acid treated corn stover enzymatic hydrolysate.

b $1 \%\left(\mathrm{w} \mathrm{w}^{-1}\right)$ sodium hydroxide treated corn stover enzymatic hydrolysate.

c $2 \%\left(\mathrm{w} \mathrm{w}^{-1}\right)$ sulfuric acid treated corn stover co-hydrolysate.

d $2 \%\left(\mathrm{w} \mathrm{w}^{-1}\right)$ sulfuric acid and $2 \%\left(\mathrm{w} \mathrm{w}^{-1}\right)$ sodium hydroxide treated corn stover combined hydrolysate.

$\mathrm{f}$ gds means gram dry substrate.

Table 3

Microbial lipid accumulation of M. isabellina on combined corn stover hydrolysate and synthetic hydrolysate.

\begin{tabular}{|c|c|c|c|c|c|c|c|c|c|c|}
\hline Culture methods & Carbon sources & $\begin{array}{l}\mathrm{C} \mathrm{N}^{-1} \\
\left(\mathrm{~mol} \mathrm{~mol}^{-1}\right)\end{array}$ & $\begin{array}{l}\text { Glucose } \\
\left(\mathrm{g} \mathrm{L}^{-1}\right)\end{array}$ & $\begin{array}{l}\text { Xylose } \\
\left(\mathrm{g} \mathrm{L}^{-1}\right)\end{array}$ & $\begin{array}{l}\text { Acetate } \\
\left(\mathrm{g} \mathrm{L}^{-1}\right)\end{array}$ & $\begin{array}{l}\operatorname{Lipid}_{\max } \\
\left(\mathrm{L}, \mathrm{g} \mathrm{L}^{-1}\right)\end{array}$ & $\begin{array}{l}\% \text { Yield } \\
\max _{\mathrm{L} / \mathrm{X}} \\
\left(\mathrm{g} \mathrm{g}^{-1}\right)\end{array}$ & $\begin{array}{l}\% \text { Yield } \\
\max _{\mathrm{L} / \mathrm{S}} \\
\left(\mathrm{g} \mathrm{g}^{-1}\right)\end{array}$ & $\begin{array}{l}\text { Lipid } \\
\text { productivity } \\
\left(\mathrm{g} \mathrm{L}^{-1} \mathrm{~d}^{-1}\right)\end{array}$ & $\begin{array}{l}\text { Biodiesel } \\
\text { productivity } \\
\left(\mathrm{g} \mathrm{L}^{-1} \mathrm{~d}^{-1}\right)\end{array}$ \\
\hline \multirow[t]{2}{*}{ Flask culture } & $\begin{array}{l}\text { Synthetic } \\
\text { hydrolysate }\end{array}$ & 58.2 & 17.9 & 12.5 & 3.7 & 5.4 & 36.6 & 16.0 & 1.8 & 0.36 \\
\hline & $\begin{array}{l}\text { Combined corn } \\
\text { stover } \\
\text { hydrolysate }\end{array}$ & 65.3 & 22.2 & 12.0 & 3.9 & 5.1 & 29.7 & 13.7 & 1.3 & 0.26 \\
\hline Fermentor culture & $\begin{array}{l}\text { Combined corn } \\
\text { stover } \\
\text { hydrolysate }\end{array}$ & 91.0 & 28.6 & 16.1 & 3.4 & 6.9 & 37.0 & 14.7 & 0.90 & 0.18 \\
\hline
\end{tabular}

(1) Data represent the average of two replicates.

\subsubsection{Fungal lipid production using $7.5 \mathrm{~L}$ bioreactor}

Fungal lipid accumulation was also carried out in a $7.5 \mathrm{~L}$ bioreactor using the combined hydrolysate medium including carbon sources of $28.6 \mathrm{~g} \mathrm{~L}^{-1}$ glucose, $16.1 \mathrm{~g} \mathrm{~L}^{-1}$ xylose, and $3.4 \mathrm{~g} \mathrm{~L}^{-1}$ acetate. The fungus experienced a lag phase around $2 \mathrm{~d}$, and then had a similar growth pattern with the flask culture on the combined hydrolysate. Most of the substrates were consumed after $184 \mathrm{~h}$ culture. The culture generated $18.7 \mathrm{~g} \mathrm{~L}^{-1}$ cell mass and $6.9 \mathrm{~g} \mathrm{~L}^{-1}$ cellular lipid (Table 3 ). While the lipid productivity and lipid yield with respect to the total amount of carbon sources (glucose, xylose, and acetate) were $0.90 \mathrm{~g} \mathrm{~L}^{-1} \mathrm{~d}^{-1}$ and $0.15 \mathrm{~g} \mathrm{~g}^{-1}$, respectively (Table 3 ). The results showed that cell mass and lipid production from the $7.5 \mathrm{~L}$ fermentation were similar with those from the flask culture, which, to certain extent, indicated that lipid production using $M$. isabellina could be effectively scaled up.

\subsection{Lipid and biodiesel production using the novel combined hydrolysis}

According to our previous study of oleaginous fungal lipid accumulation on pure glucose, xylose and corn stover co-hydrolysate (Ruan et al., 2012, 2013), 170 and $140 \mathrm{~kg}$ of lipid could be produced per ton of glucose and xylose, respectively, and $62 \mathrm{~kg}$ of lipid per ton dry corn stover could be obtained from $M$. isabellina fermentation. It has been reported that theoretical biodiesel yield per ton of glucose and xylose would be 88 and 40 gallons, respectively (Zheng et al., 2012). The theoretical biodiesel yield using $M$. isabellina for microbial lipid production is 57 gallons per ton of corn stover. Based on the lipid yield of M. isabellina in this study using $7.5 \mathrm{~L}$ bioreactor culture, $60 \mathrm{~kg}$ lipid per ton dry corn stover could be produced by $M$. isabellina fermentation on the combined hydrolysate (Table 2), 3.6 gallon biodiesel could be produced from this $60 \mathrm{~kg}$ fungal lipid by direct methanolysis using the Indarti transesterification method (Indarti et al., 2005). Even though lipid and biodiesel yields from the current study are lower than the theoretical yields, $M$. isabellina fermentation on combined hydrolysate has demonstrated better performance than other oleaginous microbes such as Trihisporon cutaneum and Rhodotorula graminis (Galafassi et al., 2012; Liu et al., 2012). T. cutaneum was cultured on detoxified corn stover hydrolysate, while $R$. graminis fermented undetoxified corn stover hydrolysate. Both fermentations produced approximately $46 \mathrm{~kg}$ lipid. It is believed that both lipid and biodiesel yields from $M$. isabellina could be further improved with optimization of combined hydrolysis and fermentation process as well as microbial lipid transesterification. The study is being fulfilled in authors' research group.

\section{Conclusion}

This study demonstrated that combined hydrolysis process was a technically feasible and promising strategy that maximized lignocellulosic biomass conversion. It minimized the need for detoxification, solid washing, and buffer addition for enzymatic hydrolysis, resulting in significantly reduced water and chemical 
usages. M. isabellina ATCC 42613 exhibited unique characteristics of utilizing glucose, xylose and acetic acid in the combined hydrolysate to accumulate fungal lipids, as well as tolerating a variety of inhibitors from feedstock pretreatment. The results indicated that the integration of $M$. isabellina lipid fermentation with novel combined hydrolysis would have great potential to advance lignocellulosic biofuel production.

\section{References}

Alvira, P., Tomás-Pejó, E., Ballesteros, M., Negro, M., 2010. Pretreatment technologies for an efficient bioethanol production process based on enzymatic hydrolysis: a review. Bioresour. Technol. 101, 4851-4861.

Chen, X., Li, Z., Zhang, X., Hu, F., Ryu, D.D., Bao, J., 2009. Screening of oleaginous yeast strains tolerant to lignocellulose degradation compounds. Appl. Biochem. Biotechnol. 159, 591-604.

de Vrije, T., de Haas, G.G., Tan, G.B., Keijsers, E.R.P., Claassen, P.A.M., 2002. Pretreatment of Miscanthus for hydrogen production by Thermotoga elfii. Int. J. Hydrogen Energy 27, 1381-1390.

Economou, C.N., Aggelis, G., Pavlou, S., Vayenas, D.V., 2011a. Modeling of single-cell oil production under nitrogen-limited and substrate inhibition conditions. Biotechnol. Bioeng. 108, 1049-1055.

Economou, C.N., Aggelis, G., Pavlou, S., Vayenas, D.V., 2011b. Single cell oil production from rice hulls hydrolysate. Bioresour. Technol. 102, 9737-9742.

Economou, C.N., Makri, A., Aggelis, G., Pavlou, S., Vayenas, D.V., 2010. Semi-solid state fermentation of sweet sorghum for the biotechnological production of single cell oil. Bioresour. Technol. 101, 1385-1388.

Fakas, S., Papanikolaou, S., Batsos, A., Galiotou-Panayotou, M., Mallouchos, A., Aggelis, G., 2009. Evaluating renewable carbon sources as substrates for single cell oil production by Cunninghamella echinulata and Mortierella isabellina. Biomass Bioenergy 33, 573-580.

Galafassi, S., Cucchetti, D., Pizza, F., Franzosi, G., Bianchi, D., Compagno, C., 2012. Lipid production for second generation biodiesel by the oleaginous yeast Rhodotorula graminis. Bioresour. Technol. 111, 398-403.

Gong, Z.W., Shen, H.W., Wang, Q., Yang, X.B., Xie, H.B., Zhao, Z.B.K., 2013. Efficient conversion of biomass into lipids by using the simultaneous saccharification and enhanced lipid production process. Biotechnol. Biofuels 6, 36 .

Halim, R., Danquah, M.K., Webley, P.A., 2012. Extraction of oil from microalgae for biodiesel production: a review. Biotechnol. Adv. 30, 709-732.

Hu, C.M., Wu, S.G., Wang, Q., Jin, G.J., Shen, H.W., Zhao, Z.B.K., 2011. Simultaneous utilization of glucose and xylose for lipid production by Trichosporon cutaneum. Biotechnol. Biofuels 4, 25.

Hu, C., Zhao, X., Zhao, J., Wu, S., Zhao, Z.K., 2009. Effects of biomass hydrolysis byproducts on oleaginous yeast Rhodosporidium toruloides. Bioresour. Technol. $100,4843-4847$.

Huang, C., Zong, M.-H., Wu, H., Liu, Q.-P., 2009. Microbial oil production from rice straw hydrolysate by Trichosporon fermentans. Bioresour. Technol. 100, 45354538.

Indarti, E., Majid, M.I.A., Hashim, R., Chong, A., 2005. Direct FAME synthesis for rapid total lipid analysis from fish oil and cod liver oil. J. Food Compos. Anal. 18, 161170.

Li, C., Knierim, B., Manisseri, C., Arora, R., Scheller, H.V., Auer, M., Vogel, K.P., Simmons, B.A., Singh, S., 2010. Comparison of dilute acid and ionic liquid pretreatment of switchgrass: biomass recalcitrance, delignification and enzymatic saccharification. Bioresour. Technol. 101, 4900-4906.
Liu, W., Wang, Y., Yu, Z., Bao, J., 2012. Simultaneous saccharification and microbial lipid fermentation of corn stover by oleaginous yeast Trichosporon cutaneum. Bioresour. Technol. 118, 13-18.

Lynd, L.R., Laser, M.S., Brandsby, D., Dale, B.E., Davison, B., Hamilton, R., Himmel, M., Keller, M., McMillan, J.D., Sheehan, J., Wyman, C.E., 2008. How biotech can transform biofuels. Nat. Biotechnol. 26, 169-172.

Lynd, L.R., van Zyl, W.H., McBride, J.E., Laser, M., 2005. Consolidated bioprocessing of cellulosic biomass: an update. Curr. Opin. Biotechnol. 16, 577-583.

Mosier, N., Wyman, C., Dale, B., Elander, R., Lee, Y.Y., Holtzapple, M., Ladisch, M., 2005. Features of promising technologies for pretreatment of lignocellulosic biomass. Bioresour. Technol. 96, 673-686.

Papanikolaou, S., Fakas, S., Fick, M., Chevalot, I., Galiotou-Panayotou, M., Komaitis, M., Marc, I., Aggelis, G., 2008. Biotechnological valorisation of raw glycerol discharged after bio-diesel (fatty acid methyl esters) manufacturing process: production of 1,3-propanediol, citric acid and single cell oil. Biomass Bioenergy 32, 60-71.

Papanikolaou, S., Galiotou-Panayotou, M., Fakas, S., Komaitis, M., Aggelis, G., 2007. Lipid production by oleaginous Mucorales cultivated on renewable carbon sources. Eur. J. Lipid Sci. Technol. 109, 1060-1070.

Ruan, Z.H., Zanotti, M., Wang, X.Q., Ducey, C., Liu, Y., 2012. Evaluation of lipid accumulation from lignocellulosic sugars by Mortierella isabellina for biodiesel production. Bioresour. Technol. 110, 198-205.

Ruan, Z.H., Zanotti, M., Zhong, Y., Liao, W., Ducey, C., Liu, Y., 2013. Co-hydrolysis of lignocellulosic biomass for microbial lipid accumulation. Biotechnol. Bioeng. 110, 1039-1049.

Scordia, D., Cosentino, S.L., Lee, J.-W., Jeffries, T.W., 2012. Bioconversion of giant reed (Arundo donax L.) hemicellulose hydrolysate to ethanol by Scheffersomyces stipitis CBS6054. Biomass Bioenergy 39, 296-305.

Sluiter, A., Hames, B., Ruiz, R., Scarlata, C., Sluiter, J., Templeton, D., Crocker, D., 2008 Determination of structural carbohydrates and lignin in biomass laboratory analytical procedure (LAP): issue date, 4/25/2008. In: Technical Report NREL/ TP-510-42618, National Renewable Energy Laboratory, Golden, Colo., pp. 16 p. digital, PDF file.

Taherzadeh, M.J., Karimi, K., 2008. Pretreatment of lignocellulosic wastes to improve ethanol and biogas production: a review. Int. J. Mol. Sci. 9, 16211651.

Teater, C., Yue, Z., MacLellan, J., Liu, Y., Liao, W., 2011. Assessing solid digestate from anaerobic digestion as feedstock for ethanol production. Bioresour. Technol. 102, 1856-1862.

Vamvakaki, A.N., Kandarakis, I., Kaminarides, S., Komaitis, M., Papanikolaou, S., 2010. Cheese whey as a renewable substrate for microbial lipid and biomass production by Zygomycetes. Eng. Life Sci. 10, 348-360.

Wooley, R., Ruth, M., Sheehan, J., Ibsen, K., Majdeski, H., Galvez, A., 1999. Lignocellulosic biomass to ethanol process design and economics utilizing cocurrent dilute acid prehydrolysis and enzymatic hydrolysis current and futuristic scenarios. DTIC Document.

Xu, J.L., Cheng, J.J., Sharma-Shivappa, R.R., Burns, J.C., 2010. Sodium hydroxide pretreatment of switchgrass for ethanol production. Energy Fuels 24, 21132119.

Zeng, J.J., Zheng, Y.B., Yu, X.C., Yu, L., Gao, D.F., Chen, S.L., 2013. Lignocellulosic biomass as a carbohydrate source for lipid production by Mortierella isabellina. Bioresour. Technol. 128, 385-391.

Zhang, J., Hu, B., 2012. Solid-state fermentation of Mortierella isabellina for lipid production from soybean hull. Appl. Biochem. Biotechnol. 166, 1034-1046.

Zhao, Z., 2005. Toward cheaper microbial oil for biodiesel oil. Zhongguo Sheng Wu Gong Cheng Za Zhi 25, 8.

Zheng, Y., Yu, X., Zeng, J., Chen, S., 2012. Feasibility of filamentous fungi for biofuel production using hydrolysate from dilute sulfuric acid pretreatment of wheat straw. Biotechnol. Biofuels 5, 50. 